\title{
The Effect of Catalyst Ratio on the Pyrolysis Yields for Waste Tyre
}

\author{
Falah Fahed Banihani ${ }^{1}$, Zaid Falah Bani Hani ${ }^{2}$ \\ ${ }^{1}$ Department of Chemical Engineering, Albalqa Applied University, Alhuson, Jordan \\ ${ }^{2}$ Department of Civil Engineering, JUST University, Irbed, Jordan
}

Email address:

falahbh@bau.edu.jo (F. F. Banihani)

\section{To cite this article:}

Falah Fahed Banihani, Zaid Falah Bani Hani. The Effect of Catalyst Ratio on the Pyrolysis Yields for Waste Tyre. American Journal of Chemical Engineering. Vol. 6, No. 4, 2018, pp. 60-64. doi: 10.11648/j.ajche.20180604.14

Received: August 1, 2018; Accepted: August 19, 2018; Published: September 15, 2018

\begin{abstract}
This paper focus on the thermal pyrolysis of used tyre with different catalysts at a temperature $550^{\circ} \mathrm{C}$ and at a heating rate of $15^{\circ} \mathrm{C} / \mathrm{min}$. The effect of process parameters on liquid yield, char formation and volatiles were also studied. In the present work, thermal pyrolysis of waste tyre samples with two selected catalysts, namely Jordan zeolite (zeolite Jo) and activated alumina was carried out in a fixed-bed reactor. The catalyst was mixed with feedstock in different percentages (10\%, $15 \%, 25 \%$ and $35 \% \mathrm{w} / \mathrm{w})$. The effects of catalysts and their ratio on the pyrolysis product oil were investigated and the results were compared with the results of experiments performed without catalyst under the same conditions (temperature $550^{\circ} \mathrm{C}$ at a heating rate of $150 \mathrm{C} / \mathrm{min}$ ). The maximum liquid yield obtained from pyrolysis of waste tyre via catalyst were found as $49.32 \%$ and $51.54 \%$ on using activated alumina and zeolite Jo as catalysts, respectively, while these values were $42.48 \%$, without catalyst. The mass loss of tyre was examined using the thermo gravimetric analysis profiles (TGA) at heating rate of $15^{\circ} \mathrm{C} / \mathrm{min}$ in air atmosphere from room temperature up to $600^{\circ} \mathrm{C}$. The tyre pyrolysis liquid product has been characterized including fuel properties, proximate analysis, and ultimate analysis and FTIR. Fuel properties show that it can be used as liquid fuels.
\end{abstract}

Keywords: Catalysts, Waste Tyre, Zeolite, Pyrolysis, Bio-Oil

\section{Introduction}

Disposal of waste vehicle tyres is one of the most important problems that should be solved. It is assessed that around the world, more than one billion waste tires are produced every year [1]. The huge quantity of waste tires presently produced in the world will absolutely increment in the future as the associated automotive industries grow. The disposal of scrap tires becomes a serious environmental problem scrap tyres are not biologically degradable, and not destructible waste through time, This polymer solid waste is non-biodegradable as a result of their complex mixture of very different materials, which include several rubbers, carbon black, steel cord and other organic and inorganic components, this fact creates problems with their disposal [2]. The impact of scrap tyres on the environment can be minimized by recycling with material or energy recovery [3]. As the disposal of scrap tyres in landfills is prohibited in many countries including Jordan, it is important to find an alternative route to take advantage of their high potential as energetic and raw material source. Subsequently, the tyre Pyrolysis, as a process to recover tyre energy, offers products that may likewise change regarding yield, chemical composition and characteristics. Even so, tyre Pyrolysis liquids have been found as a mixture of paraffin's, olefins and aromatic compounds, In addition, some physicochemical properties of the tyre Pyrolysis liquids are fairly comparable to those found in commercial automotive diesel fuels $[4,5,6]$. Consequently, pyrolysis has received renewed attention as the process conditions can be optimized to produce high valued products. pyrolysis usually proceeds at low $\left(<400^{\circ} \mathrm{C}\right)$, medium $\left(400-600^{\circ} \mathrm{C}\right)$ or high temperature $\left(>600^{\circ} \mathrm{C}\right)$. Despite the fact that pyrolysis is considered a major alternative to exploit the useful chemicals and resources from waste tyre, the process is still not in high usage and this is largely due to the high amount of energy required for the process, various attempts have been made by researchers to make tyre pyrolysis an economic viable process $[5,7]$. The process being an excellent energy 
recovery route can be performed under atmospheric or reduced pressure. It is an environmentally friendly technique to thermally decompose a wide variety of wastes, including used tyres $[4,6,8$,$] . The three basic products of pyrolysis are$ solid residue (char), liquid (bio crude), and gases [6-8]. Solid residue may be used in the manufacture of activated carbon, or as solid fuel. Much interest is laid in the production of hydrocarbon liquids from waste tyres since the production of liquid product can be a substitute of fossil fuel [9-11]. It can also be used as petroleum refinery feedstock or a source of chemicals for wide industrial applications. Gaseous fraction can be used as fuel or as a source of energy for the pyrolysis process [12-15]. This paper focus on the thermal pyrolysis of used tyre with different catalysts at a temperature $550^{\circ} \mathrm{C}$ and at a heating rate of $15^{\circ} \mathrm{C} / \mathrm{min}$. The effect of process parameters on liquid yield, char formation and volatiles were also studied. The obtained liquid was characterized for different physical and chemical analysiscondition.

\section{Materials and Methods}

\subsection{Materials}

The material used for Pyrolysis was waste scrap tyre. First it was freed from metal cords and textiles, cleaned and cut into size $5 \mathrm{~mm}$. The activated alumina and zeolite Jo catalysts were selected for the catalytic Pyrolysis of waste tyre. Natural zeolite was selected as a catalyst for our application. There is an abundance of sediment beds in east Jordan. The samples were taken from the north-east region and, the purity was about $95 \%$. For activation, it was calcined at $400^{\circ} \mathrm{C}$ for 3 hours $[10,16]$. They were activated and kept in a desiccator for the experiments. The surface area, pore volume and average pore diameter of activated alumina were found as $304.7 \mathrm{~m} 2 / \mathrm{g}, 0.407 \mathrm{ml} / \mathrm{g}$ and $53.42 \mathrm{~A}$, respectively, while these values for zeolite Jo. were found, as Surface area $(\mathrm{m} 2 \cdot \mathrm{g}-1)$ 69.12, Particle diameter $(\mathrm{mm}) \mathrm{Dp}>1.6$, Pore diameter $\left(\mathrm{A}^{\circ}\right) 33.12$ and Density $(\mathrm{kg} \cdot \mathrm{m}-3) 2150[17,18]$

\subsection{Experimental Procedure}

Pyrolysis of scrap tyres was performed in stainless steel batch reactor, volume of $310 \mathrm{~cm}^{3}$ and is externally heated by an electric furnace with the temperature being controlled by a thermocouple inside the bed. The experiments were conducted to decide the effect of catalyst ratio on the pyrolysis yields for waste tire samples, during experiments 20 gram of waste tyres having average particle size of 0.45 0.65 , was mixed with catalyst $(10 \%, 15 \%, 25 \%$ and $35 \%$ $\mathrm{w} / \mathrm{w})$ and after that put into the reactor. The optimum experimental conditions determined in a previous study were a final pyrolysis temperature of $550^{\circ} \mathrm{C}$, a heating rate of $15^{\circ} \mathrm{C}$ $/ \mathrm{min}$, a sweeping gas flow rate of $50 \mathrm{ml} / \mathrm{min}$ [10]. The vapor from the reactor was condensed in a water cooled condenser and the non-condensable gas vented to atmosphere. The liquid phase was collected from the outlet of the condenser in cold measuring cylinder and weighed. After pyrolysis, the solid char was removed and weighed, then the gas yield was calculated by the difference.

\subsection{Analysis}

The elemental analysis was done using Elementor CHNS analyzer. Thermo gravimetric analysis (TGA) of waste tyres was carried out using TGA/DTG-60 at a rate of $20^{\circ} \mathrm{C} / \mathrm{min}$ in air atmosphere from room temperature up to $600^{\circ} \mathrm{C}$. to know the decomposition temperature or to find out the range of maximum degradation temperature. Functional group composition analysis of pyrolytic oil was carried out using Fourier Transform Infrared spectroscopy (FT-IR) analyzer (Perkin Elmer RX) in range 400-4000 cm-1with $8 \mathrm{~cm}-1$ resolution.

\section{Results and Discussion}

\subsection{Element Analysis of Bio-Oils}

The Element Analysis of obtained oil from scrape tire are given in Table 1. As can be seen from this table, derived oils contain less oxygen than the scrap waste tyre. The significant decrease in oxygen content of the derived oil is important contrasted with the original feedstock on the grounds that the high oxygen content is not attractive for the production of transport fuels. Further comparison of the $\mathrm{H} / \mathrm{C}$ ratios with conventional fuels shows that the $\mathrm{H} / \mathrm{C}$ ratios of the utilized tire oils got via catalyst are similar to those of petroleum diesel oil.

Table 1. Element analysis of waste tyre and pyrolytic oil.

\begin{tabular}{|c|c|c|c|c|c|}
\hline & waste tire & $\begin{array}{l}\text { Pyrolytic oil without } \\
\text { catalyst }\end{array}$ & $\begin{array}{l}\text { Pyrolytic oil via } \\
\text { alumina catalyst }\end{array}$ & $\begin{array}{l}\text { Pyrolytic oil Via zeolite } \\
\text { Jo }\end{array}$ & petroleum diesel oil \\
\hline Carbon $(\mathrm{C})$ & 81.48 & 84.48 & 85.18 & 86.22 & 87.2 \\
\hline Hydrogen $(\mathrm{H})$ & 7.24 & 10.10 & 11.21 & 11.96 & 13.02 \\
\hline Sulphur (S) & 1.66 & 0.93 & 0.91 & 0.88 & - \\
\hline Oxygen $(\mathrm{O})$ & 4.03 & 2.27 & 1.23 & 1.11 & - \\
\hline $\mathrm{H} / \mathrm{C}$ & 1.06 & 1.42 & 1.34 & 1.38 & 1.40 \\
\hline
\end{tabular}

\subsection{Thermo Gravimetric Analysis}

TGA analysis demonstrates the decomposition behaviors during heating or it is characterized as a thermal analysis method technique which explores the mass change of sample as a component of temperature and time. From the figure 1, it predicts that two phase weight losses were watched. At initial stage first stage decomposition happen 
from $250-380^{\circ} \mathrm{C}$ which might be because of the loss of oils, plasticizers and additives present in the tyre [19]. This is followed by second phase of decomposition treated as active pyrolytic zone from $380-550^{\circ} \mathrm{C}$ which includes the continuous cracking and rapid decomposition of the other tyre parts, for example, NR, SBR [10, 20]. Amid the second stage, the intermolecular associations and weaker chemical bonds are destroyed. The side aliphatic chains might be broken and some little gaseous molecules are produced. Accordingly, the bigger molecule decomposes to smaller molecules in the form of gas phase. At that point after $550^{\circ} \mathrm{C}$ the molecule contains just fixed carbon and constant weight of ash content. Similarly many researchers reports were found that the thermal decomposition begins at $\sim 250^{\circ} \mathrm{C}$, there take after two major losses of weight during the main devolatalization, and Pyrolysis is basically complete by $550^{\circ} \mathrm{C}$ above which there is essentially no further weight reduction $[11,14,16]$.

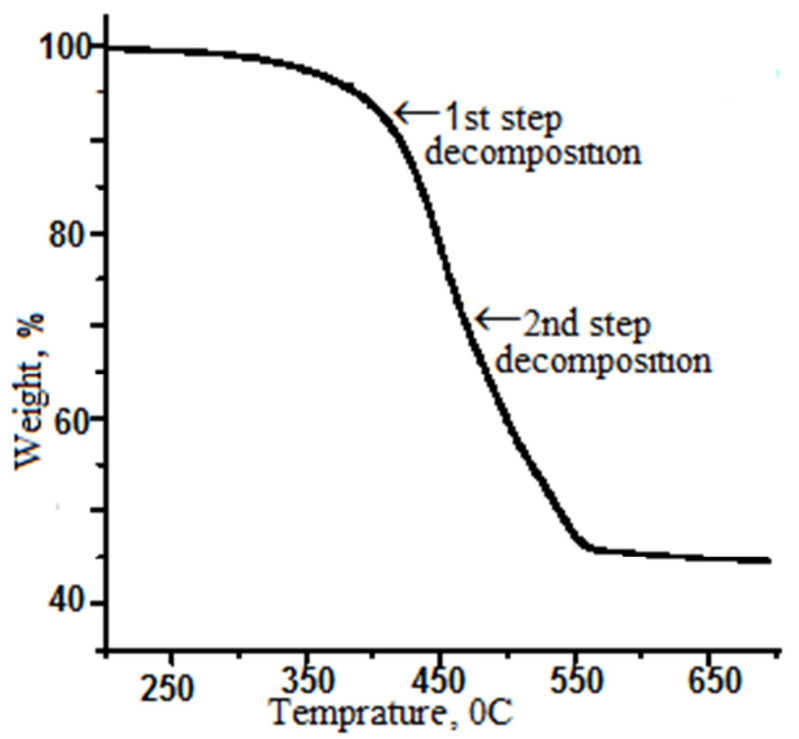

Figure 1. Thermo Gravimetric Analysis of waste tyre.

\subsection{Effect of Catalyst Ratio on the Pyrolysis Yields}

The utilized tire samples were pyrolysed to decide the impact of catalyst ratio $(10 \%, 15 \%, 25 \%$ and $35 \%)$ on the pyrolysis derived oil. The outcomes are given in Figure 2, 3 . The pyrolysis derived oil increased as the catalyst ratio increased. The obtained oil from the scrap tire, which was $42.48 \%$ without catalyst, achieved the maximum value of $49.32 \%$ on utilizing activated alumina catalyst at $15 \%$ by weight. The outcomes got with zeolite Jo, another catalyst, demonstrate that the highest obtained oil is $51.54 \%$ on utilizing this catalyst at $15 \%$ by weight. The gas product for these two catalysts smoothly expanded contrasted with the non-catalytic pyrolysis. The gas, got as $12.57 \%$ without catalyst, expanded to $14.23 \%$ with activated alumina $(35 \%$ $\mathrm{w} / \mathrm{w})$ and expanded to $15.12 \%$ with zeolite Jo $(35 \% \mathrm{w} / \mathrm{w})$ as catalysts. Pyrolysis char qualities did not change essentially in samples by using different catalyst ratios. The two catalysts have critical impacts in the perspective of expanding the bio-oil yield when it is contrasted with noncatalytic case

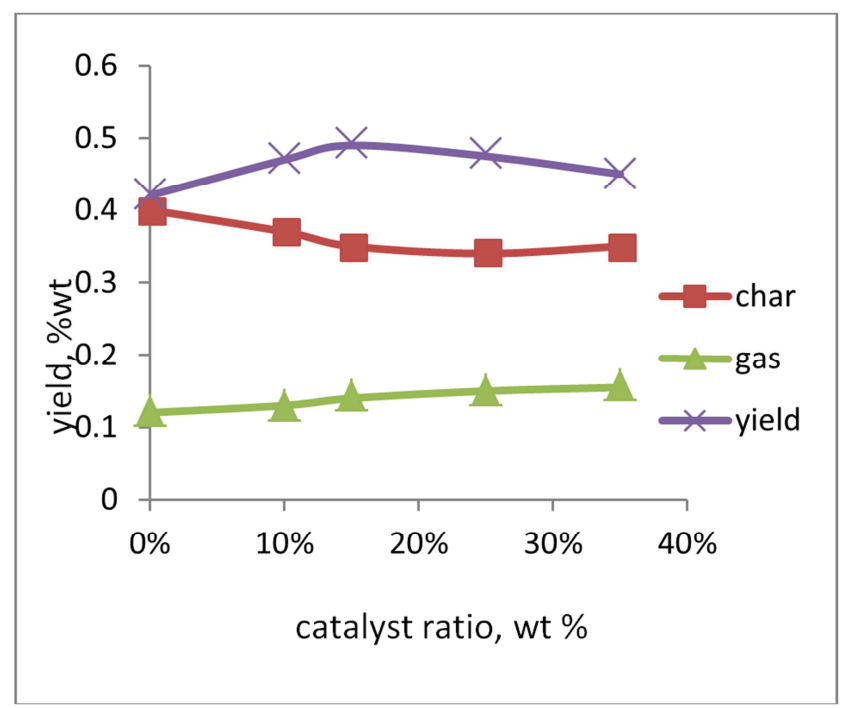

Figure 2. The change in the yields obtained from waste tier on alumina catalyst (pyrolysis temperature of $550^{\circ} \mathrm{C}$, heating rate of $15^{\circ} \mathrm{C} / \mathrm{min}$, nitrogen flow rate of $150 \mathrm{ml} / \mathrm{min}$ ).

\subsection{Physical Properties of the Pyrolytic Oil}

In table 2. fuel properties of derived oil got from pyrolysis of waste tyre, demonstrates that density of the tyre oil without catalyst was found more than that of petroleum diesel, while the density of pyrolytic oil with catalyst Pyrolysis less than that of tyre oil and similar to that of petroleum diesel. According to [10,21], low viscosity shows the positive quality in the handling and transporting of the fuel oil. The obtained flash point was low when contrasted with petroleum diesel and pyrolytic oil derived with or without catalyst. But it was more than that of gasoline. The low flash points of the tire-derived oil are not surprising since the product fuel represent unrefined liquids with a mixture of components having a wide distillation range $[11,15]$.

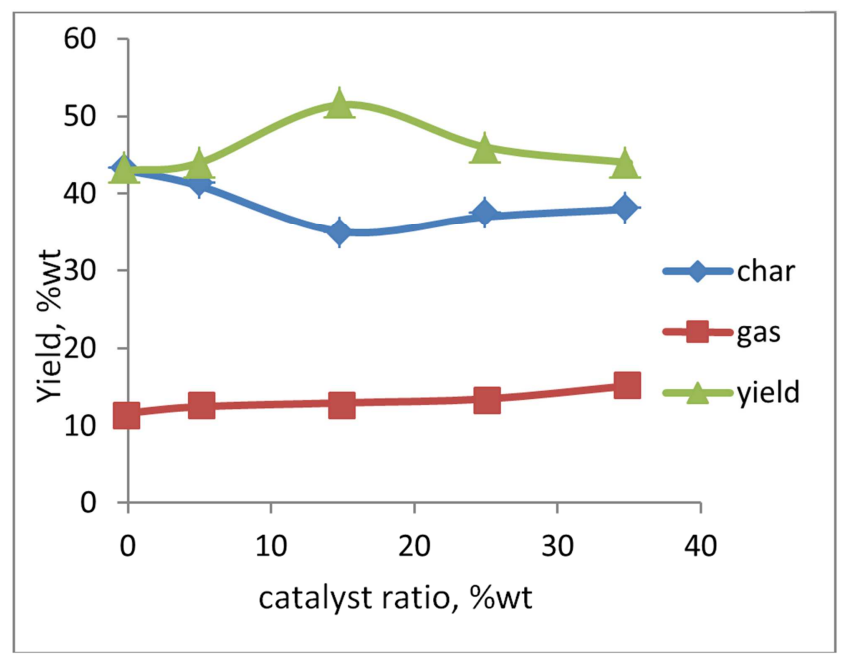

Figure 3. The change in the yields obtained from waste tier on Zeolite Jo (pyrolysis temperature of $550^{\circ} \mathrm{C}$, heating rate of $15^{\circ} \mathrm{C} / \mathrm{min}$, nitrogen flow rate of $150 \mathrm{ml} / \mathrm{min}$ ). 
The sulphur content was slightly higher than that of petroleum diesel and it is very like to light fuel oil Which is typically around $1.3-1.5 \mathrm{wt} \%$ clarified by $[15,21]$. The oil produced consisting of different fraction in the boiling range of $82-356^{\circ} \mathrm{C}$ which is to some degree like diesel. The important requirements for diesel fuel are its ignition quality, viscosity, and sulfur contents. In this manner, the pyrolytic oil require preliminary treatments such as filtration, desulphurization, and hydro treating to be utilized as fuels
The treated pyrolysis oil could be used directly as fuel oils or mixed with diesel fuels, which will reduce the viscosity and, increase the $\mathrm{pH}$ value and flash point of the resulting blends. Consequently, the atomization will be improved, ensuring a complete burnout of the fuel [18]. In light of its fuel properties, tire-derived pyrolytic oil might be considered as a valuable component for use with automotive diesel fuels. Moreover, the fuel oil may be directly used as fuels for industrial furnaces and power plants. [10, 22, 23].

Table 2. Physical properties of pyrolytic oil.

\begin{tabular}{|c|c|c|c|c|}
\hline Fuel Properties & pyrolytic oil without catalyst & pyrolytic oil via Alumina catalyst & pyrolytic oil via zeolite Jo & Diesel fuel \\
\hline Density at $20^{\circ} \mathrm{C}, \mathrm{Kg} / \mathrm{m} 3$ & 911.7 & 862.8 & 858.6 & 860 \\
\hline K. Viscosity at $40^{\circ} \mathrm{C}$ in $\mathrm{mm}^{2} / \mathrm{s}$ & 4.6 & 3.9 & 3.6 & 3.4 \\
\hline Flash point, ${ }^{\circ} \mathrm{C}$ & 50 & 55 & 56 & 60 \\
\hline Heat Value, $\mathrm{MJ} / \mathrm{Kg}$ & 43.47 & 45.5 & 48.3 & 48 \\
\hline Sulphur content, $\%$ & 1.13 & 0.37 & 0.34 & 0.2 \\
\hline Conradson Carbon Residue, $\%$ & 0.62 & 0.63 & 0.56 & 0.3 \\
\hline Diesel index & 42.4 & 50.4 & 52.1 & 55.5 \\
\hline Cetane number & 45 & 45 & 48 & 54 \\
\hline
\end{tabular}

Table 3. FT-IR Analysis of tyrepyrolytic oil.

\begin{tabular}{|c|c|c|c|c|}
\hline \multirow{2}{*}{\multicolumn{2}{|c|}{ Functional groups }} & \multicolumn{3}{|l|}{ Wave length range } \\
\hline & & \multirow{2}{*}{$\begin{array}{l}\text { uncatalysed Pyrolysis oil } \\
2955.67\end{array}$} & \multirow[t]{2}{*}{ Alumina catal. Pyrolysis oil } & \multirow[t]{2}{*}{ Zeolite Jo catal. Pyrolysis oil } \\
\hline $\mathrm{C}-\mathrm{H}$ & --------- & & & \\
\hline $\mathrm{C}-\mathrm{H}$ & Aldehyde & 2724 & 2832 & 2898 \\
\hline $\mathrm{C}=\mathrm{O}$ & -------- & 1665 & 1666 & 1679 \\
\hline $\mathrm{C}=\mathrm{C}$ & Alkane $+\mathrm{N}-\mathrm{H}$ bend & 1634 & 1626 & 1628 \\
\hline C-H & Phenyl ring Substitution & 1602 & 1602 & 1601 \\
\hline C-H & alkane & 1460 & 1457 & 1460 \\
\hline $\mathrm{C}-\mathrm{N}$ & Amines & 1290 & 1288 & 1282 \\
\hline $\mathrm{C}=\mathrm{O}$ & Alkene & 1148 & 1152 & 1148 \\
\hline C-H & Alkene & 957 & 957 & 957 \\
\hline $\mathrm{C}-\mathrm{H}$ & Alkene + Phenyl Ring Substitution & 808 & 805 & 806 \\
\hline
\end{tabular}

\subsection{FT-IR Analysis}

The FT-IR analysis of the oil indicates that, the uncataysed pyrolysis bio-oil shows the presence of oxygenated groups. For instance, peaks representing $\mathrm{C}=\mathrm{O}$ extending vibrations between 1665 and $1150 \mathrm{~cm}$. In any case, these oxygenated peaks are likewise present in the catalysed pyrolysis bio-oils recommending that the catalyst does not completely remove the oxygenated species, as as has just been appeared by the huge oxygen content in the bio-oils [10]. Table 3. also shows that, Representatives of nonoxygenated compounds were also present in the catalysed oils. Analysis of the oil shows that the functional group present mainly aromatics groups alkanes, alkenes, ketones and aldehydes, all of which have been recognized in the oil got from pyrolysis of tyres by other researchers $[12,24,25]$. For example, the $\mathrm{C}-\mathrm{H}$ extending vibrations in the vicinity of 2724 and $3000 \mathrm{~cm}$ and $\mathrm{C}-\mathrm{H}$ deformation vibrations in the vicinity of 1367 and 1460 $\mathrm{cm}$ show the presence of the functionalgroups- $\mathrm{CH} 3,-\mathrm{CH} 2$ and $-\mathrm{CH}$ which are normal for alkane groups. The adsorption peaks between 808 and $957 \mathrm{~cm}$ and 1148 and $1602 \mathrm{~cm}$ are characteristics of single ring aromatic compounds and polycyclic aromatic compounds.

\section{Conclusion}

The effect of catalyst on the product distribution demonstrates that observed that, uncataysed

Pyrolysis, decomposition was incomplete, with increase char yields and decrease in liquid and gas yield. while, at catalysed Pyrolysis, secondary cracking reaction takes place, in result, an increase in gaseous and bio-oil products is observed, the maximum bio-oil obtained from Pyrolysis of waste tyre via catalyst were found as $51.54 \%$ on using catalyst, while this value was $42.48 \%$, without catalyst. The oxygen contents were also reduced in pyrolytic oil by when use catalysts compared with bio oil obtained without catalyst.. FT-IR study on the pyrolytic oil shows that the oil obtained from catalysed Pyrolysis of waste tyre has same functional groups as compared with oil obtained from waste tyre without catalyst.

\section{Acknowledgements}

I like to acknowledge Center/environmental protaction, in 
university of AsenZalat. wherethese experiments were performed and Dr. V. Necolova for valuable discussions

\section{References}

[1] Cumali I, HüseyinA. Fuel production from waste vehicle tires by catalytic pyrolysis and its application in adieselengine., Fuel Process. Technol, Vol. 92, 2011, PP. 1129-1135.

[2] K. Naima and A. Liazid, Waste oils as alternative fuel for diesel engine:A review, Journal of Petroleum Technology and Alternative Fuels, Vol. 4 (3), 2013, pp. 30-43.

[3] J. D. Martínez, N. Puy, R. Murillo, T. García, M. V. Navarro, A. M. Mastral. Waste tyre pyrolysis-A Review, Renew. Sust. Energ. Rev. vol. 23, 2013, pp. 179-213.

[4] Julius I. Osayi, Sunny Iyuke, and Samuel E. Ogbeide, Biocrude Production through Pyrolysis of Used Tyres, Vol. 2014, Article ID 386371, pp. 9.

[5] M. Suanya, M. Thirmurugan, et. al, Recovery of oil from waste tyres using Pyrolysis method, International Journal of Research inEngineering\& Technology (IJRET), Vol. 1, Issue 2, 2013, pp. 81-90.

[6] J. D. Martinez, A. Veses, A. M. Mastral et al., Co-pyrolysis of biomass withwastetyres: upgrading of liquid to bio-fuel, Fuel Processing Technology, vol. 119, 2014, pp. 263-271.

[7] S. Frigo, M. Seggiani, M. Puccini, and S. Vitolo, Liquid fuel production from waste tyre pyrolysis and its utilization in adiesel engine, Fuel, vol. 116, 2014 pp. 399-408.

[8] H. Aydin and C. Ilkilic, Optimization of fuel production from waste vehicle tyres by pyrolysis and resembling to diesel fuel by various desulfurizationmethods, Fuel, vol. 102, 2012, pp. 605-612.

[9] M. Balat, M. Balat, E. Kirtay, and H. Balat, "Main routes for the thermo-conversion of biomass into fuels and chemicals. Part 1: pyrolysis systems," Energy Conversion andManagement, vol. 50, no. 12, 2009, pp. 3147-3157.

[10] DebalaxmiPradhan and R. K. Singh, Thermal Pyrolysis of Bicycle Waste Tyre Using Batch Reactor, International Journal of Chemical Engineering and Applications, Vol. 2, No. 5, October 2011.

[11] Islam MR, Haniu H, Beg Alam MR,. "Liquid fuels and chemicals from pyrolysis of motorcycle tyre waste Product yields, compositions and related properties. Fuel 87, 2008, pp. 3112-3122.

[12] Y. Kar, Catalytic pyrolysis of car tire waste using expanded perlite, Waste Management, vol. 31, no. 8, 2011, pp. 1772-1782.
[13] Williams PT, Bottrill RP, Cunliffe AM, Combustion of Tyre Pyrolysis Oil, TransI ChemE, Part B, Vol. 76, 1998, pp. 291301.

[14] Zahra Zamiraeia, MohammadrezaGolriza, MehranParsaa, Applying the Recyclable Waste Tire for Crude Oil Absorption, International Journal of Chemical and Environmental Engineering, Volume 8, No. 1, 2017.

[15] J. D. Martinez, A. Veses, A. M. Mastral et al., Co-pyrolysis of biomass withwaste tyres: upgrading of liquid to bio-fuel, Fuel Processing Technology, vol. 119, 2014, pp. 263-271.

[16] Juma M, Korenova Z, Markos J, Jelemensky L, Bafrnec M, Experimental study of pyrolysis and combustion of scarp tyre. Polymer for advanced technology. Vol. 18, 2007, pp. 144-148.

[17] Makhan Mia, Ariful Islam, Robiul Islam Rubel, Mohammad Rofiqul Islam, Fractional Distillation \& Characterization of Tire Derived Pyrolysis Oil, International j. of eng. Technology, Vol. 3, No. 1, 2017.

[18] FalahBanihani, Transesterification and Production of Biodiesel from Waste Cooking Oil: Effect of Operation Variables on Fuel Properties, American journal of chemical engineering, vol. 6, 2016, pp. 6 .

[19] Juan D. Martínez et. al, Co-pyrolysis of biomass with waste tyres: upgrading of the liquid bio-fuel, Fuel Processing Technology, Vol. 119, 2014pp. 263-271.

[20] [ 20] Lucia Hrušková, AndrásPeller, PavolDaučík, evaluation of crumb rubber properties term of use as modifier for asphalt, Pet Coal, Vol. 58 (3), 2016 pp. 349-358.

[21] Antoniou N, Zabaniotou A., Features of an efficient and environmentally attractive used tyresPyrolysis with energy and material recovery. Renewable and Sustainable Energy Reviews; 2012 pp. 539-558.

[22] . AdetoyeseOyedun, Ka-Leung Lam, MalteFittkau, Chi. Wai Optimization particle size in waste tyre Pyrolysis. Fuel; 2012, pp. 417-424.

[23] M. Juma, Z. Koreňová, J. Markoš, J. Annus, L'. Jelemenský, Pyrolysis and composition of scrap tire", Petroleum \& Coal, Vol. 48 (1), 2006, pp. 15-26.

[24] Mohamed Gomma Elnour1 and Hala Abbas Laz, Tire Hazardous, Disposal and Recycling, Journal of Applied and Industrial Sciences, Vol. 2 (2), 2014, pp. 63-74.

[25] Rodriguez IM, Laresgoiti MF, Cabrero MA, Torres A, Chomon MJ, Caballero B, 2001, Pyrolysis of scrap tyres, Fuel Processing Technology; Vol. 72, 2001, pp. 9-22. 